\title{
The Determinant of Whistleblowing Intention in the Case of Bank Fraud
}

\author{
Nanang Shonhadji* \\ Accounting Department, Faculty of Economics and Business, Universitas Hayam Wuruk Perbanas \\ Wonorejo Utara No 16, Jawa Timur 60296, Indonesia \\ nanang@perbanas.ac.id
}

Received: $25^{\text {th }}$ July 2020/ Revised: $20^{\text {th }}$ October 2020/ Accepted: $25^{\text {th }}$ November 2020

How to Cite: Shonhadji, N. (2021). The Determinant of Whistleblowing Intention in the Case of Bank Fraud. Binus Business Review, 12(2), 151-164. https://doi.org/10.21512/bbr.v12i2.6593

\begin{abstract}
Banking transactions in Indonesia have experienced very rapid development in line with the need for financing in the real sector. However, along with this rapid development, fraud is still a classic problem in the banking sector. The research aimed to empirically prove the effect of professional commitment, moral courage, idealism, and altruistic values on the intention to do whistleblowing. In addition, the research also investigated whether the locus of control was a variable that moderated the relationship. A quantitative research method using questionnaire instruments was used for data collection. The population was all employees of banks operating in Surabaya. The research sample included the employees of national private banks operating in Surabaya. The data analysis technique was the path analysis test with the WarpPLS program. The results show that professional commitment, moral courage, and idealism have a significant effect on the intention to do whistleblowing. Meanwhile, altruistic values do not affect the intention to do whistleblowing. The results also indicate that locus of control is a moderating variable that strengthens the relationship of professional commitment, moral courage, and idealism in affecting the intention to do whistleblowing. Professional commitment, moral courage, and idealism have become strong awareness for bank employees to participate in eradicating corruption, white-collar crime, and all forms of fraud in the organizational environment.
\end{abstract}

Keywords: whistleblowing intention, bank fraud, professional commitment, moral courage, idealism, altruistic value

\section{INTRODUCTION}

Banking transactions in Indonesia have experienced very rapid development in line with the need for financing in the real sector and the ease of banking transactions that have been adapted to the needs of customers who want fast and practical services. The investment in information technology to support the ease of banking transactions is the main capital to achieve an optimal level of company satisfaction. However, along with this rapid development, fraud is still a classic problem in the banking sector. Inevitably, fraud is a dimension of crime that is closely related to unscrupulous banking people. It can happen because the bank is a place to raise large amounts of public funds, and there are large amounts of lending to offset the spread of income that the bank wants to obtain.
The process of raising funds and channeling funds is a gap and an area for fraud to occur. Uniquely, fraud in the banking sector is very complex and mostly involves a third person: the customer or the person inside the bank. Moreover, the disclosure of the fraud is also very unique because, in general, the case is disclosed by the co-workers of the perpetrator inside the bank. The fraud is sometimes known without going through an internal audit process. It is what is known as whistleblowing.

A whistleblower is a person who has the dedication, responsibility, and professional commitment to what he considers to be fraud or crime that needs to be ended and prevented (Owusu, Bekoe, Anokye, \& Okoe, 2020; Tumuramye, Ntayi, \& Muhwezi, 2018). Serving customers honestly and having a high commitment to carry out work 
properly and responsibly are a manifestation of the values of a whistleblower's professional commitment (Alleyne, Haniffa, \& Hudaib, 2019). However, the whistleblowers must have not only professional responsibility. He must also have the moral courage to disclose fraud that occurs in the work environment. The whistleblower is someone who has the courage to disclose crime or fraud committed by his colleagues in the work environment (Latan, Jabbour, \& De Sousa Jabbour, 2019b). The whistleblower consciously dares to reveal the crime or fraud committed by a person, even though the person is someone that he knows well. In carrying out his duties, the whistleblower often intersects with behavioral aspects, which also become obstacles to become a whistleblower. The principle of strong idealism that is inherent will help a whistleblower to carry out the duties. The whistleblower will be a key informant in disclosing fraud and crime cases in the work environment.

However, it is not easy to determine and choose to become a whistleblower. It is closely related to inner conflicts that include ethical and unethical behavior or inappropriate and inappropriate behavior because the revealed problem is a crime committed by someone he knows well or even by someone who has been closest to him (Alleyne, Hudaib, \& Haniffa, 2018; Afe, Abodohoui, Mebounou, \& Karuranga, 2019). The motivation for becoming a whistleblower in some literature is very diverse. Some are motivated because they want to show professional responsibility and maintain idealism, but others are motivated because of altruistic value. This value is a form of one's responsibility to God in their daily activities. Furthermore, many studies reveal that a person's intention to become a whistleblower is a form of altruistic value. The form of altruistic value in a person arises when the person sees and knows the crime. Then, that person will provide real information based on the knowledge he knows that can be proven so that his intention to do whistleblowing is also getting stronger.

Developments in psychology and criminal law have even revealed a strong relationship between the desire for achievement and self-actualization as a form of self-recognition in the work environment which helps to strengthen one's intention to do whistleblowing (Indrasari \& Wardhana, 2020; Kyu Wang, Fu, \& Yang, 2018). This condition is known as locus of control. The existence and tendency of someone to be a whistleblower seem to be an oasis in the midst of the many cases of fraud that become socio-economic problems in the banking sector. The existence of whistleblowers has an important position in the community to reduce the occurrence of fraud, white-collar crime, and cheating. The results of an investigation conducted by ACFE in 2019 revealed that $50,2 \%$ of the detection of fraud in the business environment originated from employees' complaints and information in the internal environment of the organization itself (ACFE, 2019).

Previous studies conducted by Latan, Ringle, and Jabbour (2018) and Hechanova and Manaois (2020) provide much information that employees who are aware of fraud in their company's internal environment are reluctant to disclose it because they think that it is not their concern and responsibility. In addition, they also consider and ask about guarantees for the safety and sustainability of their work. According to Zhou, Liu, Chen, and Zhao (2018), people's intention to become whistleblower is influenced by three aspects: attitudes within themselves, subjective norms, and perceptions of control that exist within them. Another previous research also mentions that someone's intention to become a whistleblower is motivated by professional commitment to disclose the crimes and fraud she/he knows. It can be concluded that there is a relationship between one's professional commitment and the desire to become a whistleblower (Owusu et al., 2020).

In contrast to previous studies, some researchers investigate the determinants of one's desire to be willing to be a whistleblower in the profession as operations manager, corporate internal accountant, academic professional, consultant, and financial analyst through consideration of moral decisions (Park \& Lewis, 2019; Afe et al., 2019). The determinants can include identifying ethical issues, the reasons for making moral considerations, and the motivation to become a whistleblower (Pillay, Ramphul, Dorasamy, \& Meyer, 2018; Zhou et al., 2018). It shows that the intensity of moral consideration and motivation has a significant influence on the intention to become a whistleblower. Meanwhile, it shows that attitude, subjective norms, professional commitment, moral courage, and idealism influence the intention to do whistleblowing against acts of fraud or crime (Valentine \& Godkin, 2019). Therefore, the research aims to examine whether professional commitment, moral courage, idealism, and altruistic values have an effect on the intention to conduct whistleblowing with the locus of control as a moderating variable in fraud cases in the banking sector.

Banking services focus on providing excellent service for customer satisfaction. Therefore, professional commitment as a bank employee is needed. Professional commitment is formed based on knowledge and experience about the identity of the profession as a banker. A firm and consistent attitude towards the values of the profession as a banker that is formed is a professional commitment (Nawawi \& Salin, 2018; Rustiarini \& Sunarsih, 2017). A strong professional commitment will foster a love of the profession that is practiced. Professional commitment is a strong belief in loyalty, determination, persistence, and hope directed by a professional system to act according to rules and procedures that have been mutually agreed upon to achieve organizational goals (Joneta, Anugerah, \& Susilatri, 2016). According to Surya, Zarefar, and Mela (2017), professional commitment is a form of a person's love and determination towards the profession. In this case, the profession can be interpreted as bank employees who carry out the activities in accordance with the 
norms and rules that apply in the environment of their profession. Strong professional commitment will also encourage and strengthen bank employees to become agents of the truth information to find fairness to fraud around the organization's environment (Putra \& Wirasedana, 2017; Zalmi, Syofyan, \& Afriyenti, 2019). Professional commitment is also a means for bank employees to actualize themselves to be useful for the company and the community that uphold honesty and truth (Putra \& Hariyani, 2018). The inherent factors in professional commitment within a person are confidence and determination in accepting true, good, and honest values.

Then, morals are abstract rules that are inherent in bank employees in their professional environment formed based on their experiences and life beliefs. Moral courage is a form of actualizing the identity of bank employees to be brave mentally and spiritually to behave and express the value of goodness in accordance with religious, social, and legal norms. Therefore, immoral individuals are individuals who are unable to express goodness (Valentine \& Godkin, 2019). The bank has an interest in extending the loan as much as possible. However, on the other hand, the customers want the bank to approve the loan application in accordance with their wishes. The fact is that there is a moral conflict in the transaction whether to disburse a bank loan without the condition of receiving a reward when the loan application is approved or not. Ethical considerations will be a way to resolve these conditions. Ethical considerations are the building blocks of moral courage of bank employees to make ethical decisions that are free from conflicts of interest. The more mature the ethical attitude of bank employees is, the stronger their moral courage to reveal the truth will be (Triantoro, Utami, \& Joseph, 2020). This moral courage leads bank employees to have a strong intention to express and inform a real situation based on ethical considerations. The results of research conducted by Putra and Hariyani (2018) show that moral courage influences the intention to do whistleblowing. In short, it means that whistleblower must have the strong moral courage to reveal the facts of a crime and fraud correctly and honestly (Park \& Lewis, 2019).

Idealism is believed to be something appropriate and true according to intellectual thought and beliefs. Every individual in an organizational environment must have a different idealism. These differences occur because those that uphold the values of idealism formed in the individuals and those that can reduce the firmness of their idealistic values are the situations and conditions encountered in activities in their organizational environment (Effendi \& Nuraini, 2019). The bank employees' idealism that is believed to be the shared truth is the willingness of the bank employees to help and try to provide the best possible service to their customers. Therefore, when there are problems that will harm the customer and organization, the attitude of idealism to dare to express things that are believed to be ideal, good, and right will be done. This value strengthens the idealistic bank employees to have the intention to do whistleblowing easily. Hence, idealism is related to actions that are guided by ethical and moral values (Latan, Jabbour, \& De Sousa Jabbour, 2019a). Professionals, including bank employees with high idealism, should maintain their independence and integrity in deciding because they will not be easily influenced by offers of economic rewards or other rewards that can drop their credibility and integrity as bank employees. Based on Nawawi and Salin (2019), idealism has a strong influence on the intention to do whistleblowing. The used approach is the value of ethical decision-making. Ethical decisions encourage someone to be willing to be a whistleblower. Similarly, according to Pillay, Reddy, and Morgan (2017), an individual's idealism encourages and reinforces the intention to do whistleblowing.

Then, altruism is the act of giving priority to others over oneself. This act is pure nature in many cultures and the core of many religions. Altruistic behavior does not stop only on the act itself, but this behavior is also an indication of altruistic morality. Altruistic morality contains not only generosity or compassion but also awareness to help others (Puspitosari, 2019). Bank employees who have a strong altruistic value will reduce their selfishness. Altruism, which is inherent in the souls of bank employees, is based on the desire to advance others unconditionally. Therefore, the actions demand high quality of earnestness and responsibility. Altruism grows through the process of maturity of the soul and awareness of the nature of life to benefit others. Bank employees, who have altruistic values, will be more willing to express discrepancies or fraud as a sense of responsibility and empathy for mutual interests rather than personal interests. They tend to have an empathetic attitude shown by being tolerant and able to control themselves and have a strong motivation to help others. Altruistic traits are also closely related to beliefs in justice in the world. Therefore, it will be easier to show helpful behavior to others. According to Martin (2011), altruistic values have an influence on the intention to do whistleblowing.

Locus of control in several behavioral and management accounting studies is used as a moderating variable. Psychology, a scientific domain that deals with the locus of control, defines the locus of control as the hope desired by the majority of individuals for a reward in life that is controlled by the strengths and abilities they have or the strengths and influences of others outside them (Zarefar \& Zarefar, 2017). Events, that occur and are experienced by bank employees as the results of their actions and behavior, are the internal locus of control (Zalmi et al., 2019). The obtained experience and knowledge are an effort made consciously by the bank employees because of their hopes and desires. Someone, who has an external locus of control, believes that what happens in life is due to the influence of the surrounding community, destiny, and fate that God has determined. Bank employees, who have a strong external locus of control, realize 
that helping others is part of returning the favor of happiness that has been received because of the support of fellow bank employees, not because of their efforts. Therefore, bank employees, who have an internal and external locus of control, will strengthen their intention to be willing to do whistleblowing (Joneta et al., 2016). The effectiveness of locus of control as a moderating variable is in line with the research conducted by Zarefar and Zarefar (2017).

The intention to do whistleblowing is very risky. Therefore, it is not easy for bank employees to be willing to become whistleblowers (Andon, Free, Jidin, Monroe, \& Turner, 2018; Latan et al., 2019b). Physical and non-physical security guarantees become the main consideration in addition to the consideration of social sanctions. Bank employees who wish to become whistleblowers will at least consider ethical sensitivity to fraud or white-collar crime. In addition, the consideration includes professional competence and ethical values to dare to truthfully disclose the issues of fraud and white-collar crime that are the object of the case (Putra \& Hariyani, 2018). The research has five hypotheses as follows.

H1: Professional commitment has a significant effect on the intention to do whistleblowing.

$\mathrm{H} 2$ : Moral courage has a significant effect on the intention to do whistleblowing.

H3: Idealism has a significant effect on the intention to do whistleblowing

H4: Altruistic value has no significant effect on the intention to do whistleblowing

H5: Locus of control becomes the moderating variable of the relationship between exogenous variables and endogenous variables.
The intention to do whistleblowing cannot be done instantly. It requires the readiness of the process of the elements that are thought to influence it. The research identifies professional commitment, moral courage, idealism, and altruistic values as elements that influence whistleblowing intentions for empirical testing. The research model is shown in Figure 1.

\section{METHODS}

The quantitative empirical research is applied to find out how the influence of professional commitment, moral courage, idealism, and altruistic values on the intention to do whistleblowing with the locus of control as a moderating variable. The population of the research is all employees of banks operating in Surabaya. Then, the research sample is employees of national private banks operating in Surabaya. Surabaya is the city with the second-largest amount of money circulation after DKI Jakarta (Badan Pusat Statistik, 2019). It has a potential for fraud involving banks as a medium for circulating money.

The research uses the convenience sampling method by selecting potential respondents who are willing to fill in the questionnaire as a research instrument from November 2019 to February 2020. The questionnaire is divided into seven-question categories based on the research variables (see Appendix). Each question in the questionnaire is arranged using a Likert scale. The number of questionnaires is 200 , but those that are entirely filled and met the criteria for further data testing are only 154 questionnaires. The used data analysis technique is the path analysis technique with the WarpPLS application program.

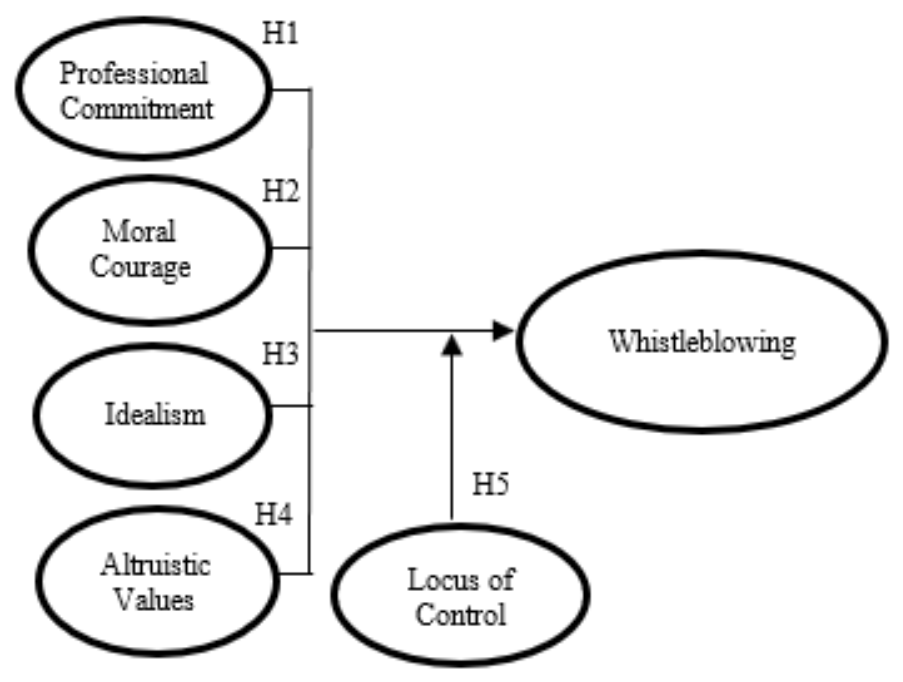

Figure 1 Research Model 


\section{RESULTS AND DISCUSSIONS}

The results of the questionnaires that the respondents return have fulfilled the requirements and expectations with a response rate of $84 \%$. The discussion includes descriptive analysis, coefficient of determination, coefficient variable test results, hypothesis testing results, and discussion of research results. The respondents with five or more years of service are $85 \%$, while those with less than five years of service are $15 \%$. Then, the respondents who understand and know the terms of fraud and whistleblower are $96 \%$. Only $4 \%$ of the respondents do not understand.

The results of the descriptive test can be seen in Table 1. It can be seen that professional commitment, moral courage, idealism, whistleblowing intention, and locus of control tend to have a mean value higher than 4. It means that most respondents give approval and a strong desire that professional commitment, moral courage, idealism, and whistleblowing intention are a statement of attitude that causes the respondents to have the intention to disclose fraud in their business organization. Meanwhile, altruistic value has a mean value of 3,2091 . The respondents tend not to give a strong attitude statement that the altruistic value is a reason to do whistleblowing.

The data in Table 2 explains the coefficient of determination (R-squared). It shows how many percentages that the independent variable influences the dependent variable. R-squared value of 0,395 explains that the variance of whistleblowing intention can be explained by variables of professional commitment, moral courage, idealism, altruistic value, and locus of control by $39,5 \%$. Then, Q-squared values can be negative or positive. If the Q-squared value is greater than 0 , the research model can be said to be feasible or has a good predictive value. Based on the calculation results, it is obtained a Q-squared value of 0,857 (greater than 0). It indicates that the research model has good predictive validity.

The values of composite reliability and Cronbach's alpha as indicators of reliability measurement in research instruments must be above 0,70 (Latan \& Ghozali, 2017). The calculation of the coefficient variable in Table 3 shows the composite reliability value of the used variables. It shows 0,875 for professional commitment, 0,831 for moral courage, 0,847 for idealism, 0,861 for altruistic values, and 0,861 for locus of control. These variables have composite reliability values greater than 0,70 . It means that the reliability of the research instrument is fulfilled. The reliability of the instrument can also be seen from the Cronbach's alpha value of the variables. The values are 0,829 for professional commitment, 0,759 for moral courage, 0,787 for idealism, 0,806 for altruistic values, and 0,807 for locus of control. All variables have Cronbach's alpha values bigger than 0,70 . Hence, it can be said that the measurement instruments for each variable meet the reliability criteria.

Furthermore, the full collinearity by Variance Inflation Factor (VIF) test results include vertical or classical and lateral collinearity. Vertical or classical collinearity is between independent variables (predictors) in the same block, which is between the independent variable and the indicator. Meanwhile, lateral collinearity is used to test common method biases. The criterion for full collinearity is that the value must be lower than 3,3 within the tolerance range smaller than 10 (Latan \& Ghozali, 2017).

Table 1 The Results of Descriptive Test

\begin{tabular}{lccc}
\hline Variable & N & Mean & Std. Dev \\
\hline Professional Commitment (PC) & 154 & 4,2602 & 0,0192 \\
Moral Courage (MC) & 154 & 4,2513 & 0,0113 \\
Idealism (ID) & 154 & 4,4956 & 0,0392 \\
Altruistic Value (AV) & 154 & 3,2091 & 0,2107 \\
Whistleblowing Intention (WI) & 154 & 4,1771 & 0,0099 \\
Locus of Control (LoC) & 154 & 4,0058 & 0,0201 \\
\hline
\end{tabular}

(Source: WarpPLS Output, 2020)

Table 2 Coefficient of Determination Values

\begin{tabular}{cc}
\hline Coefficient of Determination & Value \\
\hline R-squared & 0,395 \\
Adj. R-squared & 0,362 \\
Q-squared & 0,875 \\
\hline
\end{tabular}

(Source: Data Processed, 2020) 
Table 3 The Coefficient Variable Test Results

\begin{tabular}{lcccc}
\hline & $\begin{array}{c}\text { Composite } \\
\text { reliability }\end{array}$ & $\begin{array}{c}\text { Cronbach's } \\
\text { alpha }\end{array}$ & AVE & $\begin{array}{c}\text { Full collinearity } \\
\text { (VIF) }\end{array}$ \\
\hline Professional Commitment (PC) & 0,875 & 0,829 & 0,516 & 1,268 \\
Moral Courage (MC) & 0,831 & 0,759 & 0,541 & 3,112 \\
Idealism (ID) & 0,874 & 0,787 & 0,545 & 1,249 \\
Altruistic Value (AV) & 0,861 & 0,806 & 0,593 & 3,207 \\
Whistleblowing Intention (WI) & 0,909 & 0,882 & 0,593 & 3,215 \\
Locus of Control (LoC) & 0,861 & 0,807 & 0,585 & 2,281 \\
LoC*AV & 0,987 & 0,987 & 0,879 & 2,812 \\
LoC*ID & 0,997 & 0,997 & 0,884 & 3,025 \\
LoC*MC & 0,996 & 0,996 & 0,853 & 3,207 \\
LoC*PC & 0,974 & 0,974 & 0,888 & 3,959 \\
\hline
\end{tabular}

(Source: Data Processed, 2020)

Table 4 Hypothesis Test Results

\begin{tabular}{ccccc}
\hline Exogenous & Moderating & Endogenous & P-Value & Result \\
\hline PC & & WI & $<0,001$ & Significant \\
MC & & WI & $<0,001$ & Significant \\
ID & & WI & 0,002 & Significant \\
AV & & WI & 0,180 & Not significant \\
PC & LoC & WI & $<0,001$ & Significant \\
MC & LoC & WI & $<0,001$ & Significant \\
ID & LoC & WI & $<0,001$ & Significant \\
AV & LoC & WI & $<0,001$ & Significant \\
\hline
\end{tabular}

(Source: Data Processed, 2020)

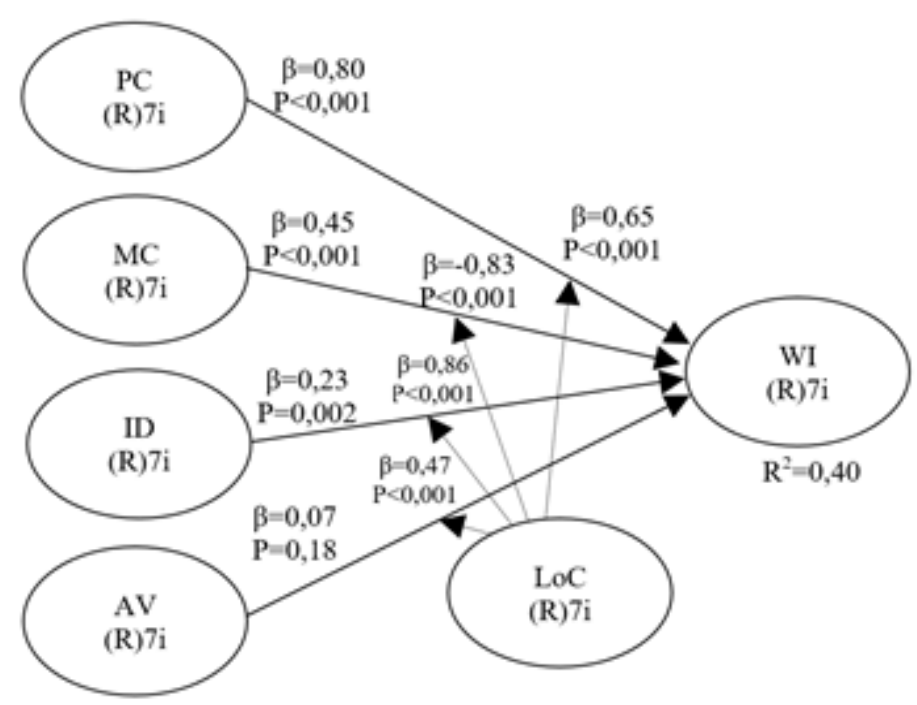

Figure 2 Outer Model 
The test results in Table 3 show that the value of full collinearity for all variables in the research is smaller than 3,3 so that the model is free from collinearity problems. Average Variance Extracted (AVE) values show 0,516 for professional commitment, 0,541 for moral courage 0,545 for idealism, 0,593 for altruistic values, and 0,585 for locus of control. These results show that the value of each variable is greater than 0,50 . Hence, the research instrument is declared valid.

Figure 2 shows that professional commitment, moral courage, and idealism have a significant effect on the intention to do whistleblowing because the P-value is smaller than 0,001 . However, altruistic value is not significant, with the P-value of 0,18 . Then, locus of control as moderation variable in the relationship of professional commitment, moral courage, idealism, and altruistic values in affecting the intention to do whistleblowing has a smaller P-value than 0,001 .

Hypothesis testing or significance testing is done to test the influence of exogenous variables on endogenous variables. If the value of t-statistics is $\geq \mathrm{t}$-table $(1,96)$ or $\mathrm{P}$-value $<\alpha=0,05$, exogenous variable has a significant effect on endogenous variable. Conversely, if the value of t-statistics is $\leq$ t-table $(1,96)$ or P-value $>\alpha=0,05$, exogenous variable has no significant effect on endogenous variable. The hypothesis test results are shown in Table 4.

The first hypothesis test results show that professional commitment has a smaller P-value than 0,001 , or it meets the criteria of $\mathrm{P}$-value $<\alpha=0,05$. It means that professional commitment has a significant effect on the intention to do whistleblowing. So, it can be concluded that the first hypothesis (H1) is accepted.

Professional commitment has a significant effect on the intention to do whistleblowing. Professional commitment is basically an individual's perception of loyalty, determination, and expectations guided by the system, values, or norms that will direct the individual to act according to certain procedures to carry out the duties with high success. Bank employees, who have a strong professional commitment, will dare to honestly reveal the facts about the phenomena of fraud that they know through consideration of the knowledge they have, as a form of their professional attitude. Strong professional commitment will also encourage and strengthen the bank employees to become agents of the truth in the fraud that occurs in their organization. Professional commitment is also a means for bank employees to actualize themselves to benefit companies and communities which uphold honesty and truth. Therefore, bank employees, who have strong professional commitment, tend to be willing and have a strong intention to do whistleblowing (Putra \& Wirasedana, 2017; Zalmi et al., 2019). This result is supported by research conducted by Putra and Hariyani (2018).

The second hypothesis test results show that moral courage has a smaller P-value than 0,001 , or it meets the criteria of P-value $<\alpha=0,05$. The results imply that moral courage has a significant effect on the intention to do whistleblowing. So, it can be concluded that the second hypothesis (H2) is accepted.

Moral courage has a significant effect on the intention to do whistleblowing. The moral courage owned by bank employees is an essential factor in disclosing fraud. The moral courage of bank employees in facing pressure will help to prevent unethical behavior (Triantoro et al., 2020). Moral courage is an act of virtue in dealing with moral challenges. Ethical considerations by bank employees will be a way to resolve these conditions. Ethical considerations are the shape of the moral courage of bank employees to make ethical decisions that are free from conflicts of interest. The more mature the ethical attitude of bank employees is, the stronger the moral courage to reveal honesty and truth will be. This moral courage leads bank employees to have a strong intention to express and inform a real situation based on ethical considerations. The result is supported by research conducted by Putra and Hariyani (2018) that moral courage has an influence on the intention to do whistleblowing. Therefore, the stronger the moral courage of a banker is, the stronger her/his intention to do whistleblowing will be. Moreover, the result is also in line with Triantoro et al. (2020).

The result of the third hypothesis testing shows that the variable of idealism has a $\mathrm{P}$-value of 0,002 or it meets the criteria of P-value $<\alpha=0,05$. Idealism has a significant effect on the intention to do whistleblowing. So, it can be concluded that the third hypothesis (H3) is accepted.

Idealism has a significant effect on the intention to do whistleblowing. Respondents believe that idealism is an action based on ethical values, morals, and things that are believed to be the truth. Bank employees, who have high idealism, will use their beliefs that they consider correct and appropriate to express the attitude and choice of action when seeing a problem. Material interests or any reward cannot influence that choice because what they believe is the truth that must be revealed. The idealism of bank employees is shaped by the process of a strong understanding of the value of life that they want to achieve. The idealism, that bank employees believe, has led to strong thought and determination. It is consistent with the suitability of the values and beliefs in their lives. Idealism in the research has been able to direct bank employees to be more consistent over something that is believed to be the truth even though others do not necessarily accept it. Therefore, the more consistent bank employees are with their idealism, the stronger their intention to do whistleblowing will be. The result is supported by the research conducted by Pillay et al. (2017) and Effendi and Nuraini (2019).

The result of the fourth hypothesis testing shows that altruistic value has a $\mathrm{P}$-value of 0,180 , or it does not meet the criteria of P-value $<\alpha=0,05$. It means that altruistic value has no significant effect on the intention to do whistleblowing. So, the fourth hypothesis (H4) is rejected.

Altruistic value has no significant effect on the intention to do whistleblowing. The result is not in 
line with Puspitosari (2019), who said religiosity had a significant effect on the intention to do whistleblowing. Religiosity is a part of altruistic values as a process of creating values and activities to get closer to God. Respondents state that having an altruistic value means having more ties to spiritual or psychological things in nature than physical or material things. The result reveals that bank employees have not had another view that the altruistic value is not only the sacrifice of personal interests in achieving meaning in life and life goals but also an effort to reduce selfishness yet. They think that the intention to do whistleblowing is a selfish act to interfere with other people's problems. Respondents also still doubt that bank employees with altruistic value tend to sacrifice for a higher value, whether it is human or divine. Altruistic value is abstract, and respondents believe that the altruistic intention that focuses on motivation to help others unconditionally is not absolute. Therefore, the result shows that altruistic values do not affect the intention to do whistleblowing. Altruistic value does not affect the intention to do whistleblowing because most respondents disagree with the questions on the altruistic value. For example, the organizational environment wants them to help solve problems committed by coworkers, revealing a truth risks their career, and there is an existence of the belief that job responsibility is individual.

The result of the fifth hypothesis testing shows that the variable of locus of control becomes the moderating variable of the relationship between exogenous variables and endogenous variable. The result of the moderation test shows that the P-value is lower than 0,001. It means that the locus of control can strengthen the relationship of professional commitment, moral courage, idealism, and altruistic value in affecting the intention to do whistleblowing. It can be concluded that the fifth hypothesis (H5) is accepted.

Locus of control can strengthen the relationship of the variables of professional commitment, moral courage, idealism, and altruistic values in affecting the intention to do whistleblowing. It strengthens the relationship of the effect of professional commitment on the intention to do whistleblowing. The research result shows that bank employees with an internal locus of control tend to believe that the obtained work performance is a reward from sacrificing professional commitments that have been maintained and implemented as well as possible. Bank employees also believe that work performance is a form of success in maintaining professional commitment with co-workers' help, and it has become part of their destiny. Therefore, the strength in bank employees and the awareness that the obtained achievements are part of the support of the work environment and destiny strengthens the effect of professional commitment on the intention to do whistleblowing.

Locus of control also strengthens the effect of moral courage on the intention to do whistleblowing. The result is supported by research conducted by
Zalmi etal.(2019). Bankemployees with characteristics related to an internal locus of control are considered to have moral courage, which is generally unacceptable in the organization where they work compared to the external locus of control. Individuals with an internal locus of control believe that an event is in their control and will always take roles and responsibilities in determining right or wrong. Meanwhile, individuals with an external locus of control are less likely to take personal responsibility for the consequences of moral courage and rely on outside forces (Zarefar \& Zarefar, 2017). Individuals with an internal locus of control are more consistent between courage and moral actions to do whistleblowing.

Similarly, locus of control helps the effect of idealism on the intention to do whistleblowing. The result is in line with the research conducted by Joneta et al. (2016). According to Joneta et al. (2016), great responsibility for honest and empathetic work behavior as a form of internal locus of control can strengthen personal relationships. It is consistent with believed values to be good guidelines in one's life towards the intention to do whistleblowing. Then, the external locus of control is good work behavior, where the obtained achievements are also caused by the support of others and a conducive organizational atmosphere. Rationality causes people who have an external locus of control to have a strong drive to create a good work environment. Therefore, it can be concluded that the locus of control can be an amplifier for people with the idealism of guidelines and beliefs in their good life goals to do whistleblowing.

Last, the result also shows that locus of control strengthens the no effect of altruistic value on the intention of bank employees to conduct whistleblowing. Bank employees feel that the altruistic value is not limited to the tendency to sacrifice for others, but it is believed to be a false abstraction of belief. It is hard to find someone who sacrifices unconditionally in the banking sector. The reality is that all bank employees compete with each other to pursue their careers and achievements by relying on the rational power of their minds and utilizing the help and roles of other employees.

\section{CONCLUSIONS}

The research aims to empirically prove the effect of professional commitment, moral courage, idealism, and altruistic values on the intention to do whistleblowing. In addition, the research also investigates whether the locus of control is the moderating variable of the relationship. Quantitative research method using questionnaire instruments is used for data collection. The results show that professional commitment, moral courage, and idealism have a significant effect on the intention to do whistleblowing. Meanwhile, the altruistic value has no effect. The results also indicate that locus of control is a moderating variable that strengthens the relationship of professional commitment, moral 
courage, and idealism in affecting the intention to do whistleblowing.

The research has a limitation. The filling out process of the questionnaire conducted by the respondents cannot be fully monitored and controlled by the researchers. The majority of respondents request questionnaires to be put on the table and filled out the next day. Thus, it can be said that the oversight and control of the questionnaire are still weak and has limitations. It will be better and faster if the questionnaire is distributed using the Google form as a research instrument. It will make it easier to control and track the questionnaire.

It is recommended that future researchers try to explore other variables that may influence whistleblowing intention, such as ambiguity in attitudes and beliefs. Professional and moral awareness and idealism have become strong awareness for bank employees to participate in eradicating corruption, white-collar crime, and all forms of fraud in the banking sector as a practical contribution in the research.

\section{REFERENCES}

ACFE. (2019). Survei Fraud Indonesia. Retrieved from https://acfe-indonesia.or.id/wp-content/ u p 1 o a d s / 2021 / 02 / S U R V E I - F R A U D INDONESIA-2019.pdf

Afe, C. E. I., Abodohoui, A., Mebounou, T. G. C., \& Karuranga, E. (2019). Perceived organizational climate and whistleblowing intention in academic organizations: Evidence from Selçuk University (Turkey). Eurasian Business Review, 9(3), 299-318. https://doi.org/10.1007/s40821-018-0110-3

Alleyne, P., Haniffa, R., \& Hudaib, M. (2019). Does group cohesion moderate auditors' whistleblowing intentions? Journal of International Accounting, Auditing and Taxation, 34(March), 69-90. https:// doi.org/10.1016/j.intaccaudtax.2019.02.004

Alleyne, P., Hudaib, M., \& Haniffa, R. (2018). The moderating role of perceived organisational support in breaking the silence of public accountants. Journal of Business Ethics, 147, 509-527. https:// doi.org/10.1007/s10551-015-2946-0

Andon, P., Free, C., Jidin, R., Monroe, G. S., \& Turner, M. J. (2018). The impact of financial incentives and perceptions of seriousness on whistleblowing intention. Journal of Business Ethics, 151, 165-178. https://doi.org/10.1007/s10551-016-3215-6

Badan Pusat Statistik. (2019). Laporan Perekonomian Indonesia 2019. Retrieved from https:// www.bps.go.id/publication/2019/09/16/7 cc68afc43aa0d8b9e8eaf47/laporan-perekonomianindonesa-2019.html.

Effendi, A., \& Nuraini, N. (2019). Pengaruh perlindungan hukum, orientasi etika idealisme, orientasi etika relativisme dan retaliasi terhadap intensi whistleblowing (Survei pada mahasiswa universitas negeri di Provinsi Aceh). Jurnal Ilmiah Mahasiswa Ekonomi Akuntansi, 4(3), 504-519. https://doi. org/10.24815/jimeka.v4i3.12586
Hechanova, M. R. M., \& Manaois, J. O. (2020). Blowing the whistle on workplace corruption: The role of ethical leadership. International Journal of Law and Management, 62(3), 277-294. https://doi. org/10.1108/IJLMA-02-2019-0038

Indrasari, A., \& Wardhana, W. (2020). The factors influencing whistleblowing intention. Journal of Talent Development and Excellence, 12(2s), 10581071.

Joneta, C., Anugerah, R., \& Susilatri. (2016). Pengaruh komitmen profesional dan pertimbangan etis terhadap intensi melakukan whistleblowing: Locus of control sebagai variabel moderasi. Jurnal Online Mahasiswa Fakultas Ekonomi Universitas Riau, 3(1), 735-748.

Kyu Wang, T., Fu, K. J., \& Yang, K. (2018). Do good workplace relationships encourage employee whistle-blowing? Public Performance \& Management Review, 41(4), 768-789. https://doi.or $\mathrm{g} / 10.1080 / 15309576.2018 .1464935$

Latan, H., \& Ghozali, I. (2017). Partial Least Squares: Konsep, metode dan aplikasi menggunakan program WarpPLS.5.0. Semarang: Badan Penerbit Universitas Diponegoro.

Latan, H., Jabbour, C. J. C., \& De Sousa Jabbour, A. B. L. (2019a). Ethical awareness, ethical judgment and whistleblowing: A moderated mediation analysis. Journal of Business Ethics, 155, 289-304. https:// doi.org/10.1007/s10551-017-3534-2

Latan, H., Jabbour, C. J. C., \& De Sousa Jabbour, A. B. L. (2019b). 'Whistleblowing triangle': Framework and empirical evidence. Journal of Business Ethics, 160, 189-204. https://doi.org/10.1007/s10551-0183862-x

Latan, H., Ringle, C. M., \& Jabbour, C. J. C. (2018). Whistleblowing intentions among public accountants in Indonesia: Testing for the moderation effects. Journal of Business Ethics, 152, 573-588. https:// doi.org/10.1007/s10551-016-3318-0

Martin, D. E. (2011). Whistle blowing, religiosity, spirituality and integrity: Understanding the impact of social dominance orientation and environmental context. Journal of Organizational Moral Psychology, 2(1), 99-116.

Nawawi, A., \& Salin, A. S. A. P. (2018). Whistle blowing intentions-Evidence from Malaysian PLC. International Journal of Law and Management, 60(5), 1111-1125. https://doi.org/10.1108/ IJLMA-04-2017-0096

Nawawi, A., \& Salin, A. S. A. P. (2019). To whistle or not to whistle? Determinants and consequences. Journal of Financial Crime, 26(1), 260-276. https://doi. org/10.1108/JFC-10-2017-0090

Owusu, G. M. Y., Bekoe, R. A., Anokye, F. K., \& Okoe, F. O. (2020). Whistleblowing intentions of accounting students: An application of the theory of planned behaviour. Journal of Financial Crime, 27(2), 477492. https://doi.org/10.1108/JFC-01-2019-0007

Park, H., \& Lewis, D. (2019). The motivations of external whistleblowers and their impact on the intention to blow the whistle again. Business Ethics: A European 
Review, 28(3), 379-390. https://doi.org/10.1111/ beer. 12224

Pillay, S., Ramphul, N., Dorasamy, N., \& Meyer, D. (2018). Predictors of whistle-blowing intentions: An analysis of multi-level variables. Administration \& Society, 50(2), 186-216. https://doi. org/10.1177/0095399715581621

Pillay, S., Reddy, P. S., \& Morgan, D. (2017). Institutional isomorphism and whistle-blowing intentions in public sector institutions. Public Management Review, 19(4), 423-442. https://doi.org/10.1080/147 19037.2016.1178322

Puspitosari, I. (2019). Whitleblowing intention sebagai bagian dari etika Islam ditinjau dari intensitas moral, orientasi etika relativisme dan religiusitas. Jurnal Iqtisaduna, 5(2), 139-152. https://doi.org/10.24252/ iqtisaduna.v5i2.10701

Putra, A. A., \& Hariyani, E. (2018). Pengaruh komitmen profesional, lingkungan etika, intensitas moral, personal cost terhadap intensi untuk melakukan whistleblowing internal (Studi empiris pada OPD Kabupaten Bengkalis). Jurnal Akuntansi Keuangan dan Bisnis, 11(2), 17-26.

Putra, I. M. D. D., \& Wirasedana, I. W. P. (2017). Pengaruh komitmen profesional, self efficacy, dan intensitas moral terhadap niat untuk melakukan whistleblowing. E-Jurnal Akuntansi Universitas Udayana, 21(2), 1488-1518.

Rustiarini, N. W., \& Sunarsih, N. M. (2017). Factors influencing the whistleblowing behaviour: A perspective from the theory of planned behaviour. Asian Journal of Business and Accounting, 10(2), 187-214
Surya, R. A. S., Zarefar, A., \& Mela, N. F. (2017). Whistle blowing in the police sector: The importance of control behaviour factor and professional commitment. Accounting and Finance Review (AFR), 2(2), 9-14.

Triantoro, H. D., Utami, I., \& Joseph, C. (2020). Whistleblowing system, Machiavellian personality, fraud intention: An experimental study. Journal of Financial Crime, 27(1), 202-216. https://doi. org/10.1108/JFC-01-2019-0003

Tumuramye, B., Ntayi, J. M., \& Muhwezi, M. (2018). Whistle-blowing intentions and behaviour in Ugandan public procurement. Journal of Public Procurement, 18(2), 111-130. https://doi. org/10.1108/JOPP-06-2018-008

Valentine, S., \& Godkin, L. (2019). Moral intensity, ethical decision making, and whistleblowing intention. Journal of Business Research, 98(May), 277-288. https://doi.org/10.1016/j.jbusres.2019.01.009

Zalmi, W. D., Syofyan, E., \& Afriyenti, M. (2019). Pengaruh komitmen profesional, locus of control, dan sosialisasi antisipatif mahasiswa terhadap whistleblowing: (Studi empiris pada mahasiswa S1 Akuntansi di Universitas Negeri Padang). Jurnal Eksplorasi Akuntansi, 1(1), 290-305.

Zarefar, A., \& Zarefar, A. (2017). The influence of ethics and locus of control to do whistle blowing intention with profession of auditor and non-auditor as a moderating variable. Accounting and Finance Review (AFR), 2(2), 35-41.

Zhou, L., Liu, Y., Chen, Z., \& Zhao, S. (2018). Psychological mechanisms linking ethical climate to employee whistle-blowing intention. Journal of Managerial Psychology, 33(2), 196-213. https://doi.org/10.1108/ JMP-09-2017-0292 


\section{APPENDIX}

\section{QUESTIONNAIRE}

Dear Respondents,

I hereby:

Name: Nanang Shonhadji

Asking Mr. / Ms. to fill out the questionnaire below in order to carry out my research entitled:

"The Determinant of Whistleblowing Intention in the Case of Bank Fraud"

The success of the research really depends on your participation in answering the questionnaire. The confidentiality of all respondent data will be guaranteed.

Thank you.

Best regards,

Nanang Shonhadji

\section{Profile}

Direction: Please fill in and put a checklist $(\sqrt{ })$ in the following statement:

Gender
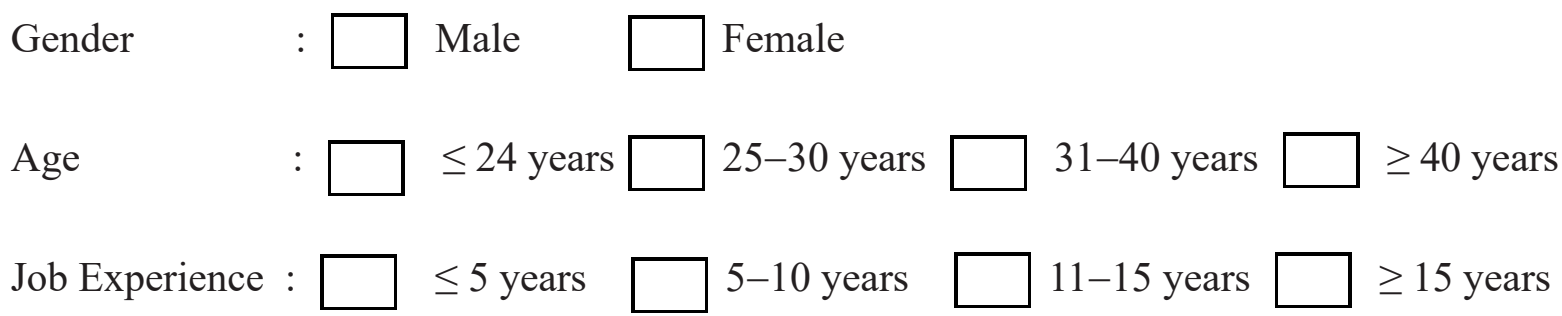

Current position:

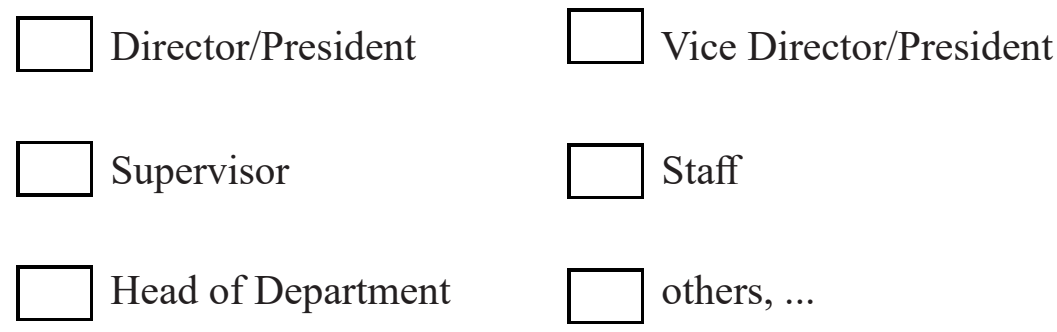

Directions: put a checklist $(\sqrt{ })$ on the answer that matches how you feel. The answer to each question is in the form of a Likert scale with the following conditions:

STS = strongly disagree

TS = disagree

$\mathrm{N}=$ neutral

$\mathrm{S} \quad=$ agree

SS = strongly agree 


\section{List of Statements for Professional Commitment Variable}

Professional commitment is the level of individuals' loyalty to their profession. It includes a sense of responsibility and goal-oriented and maintains the values that the profession believes in.

\begin{tabular}{|c|l|l|l|l|l|l|}
\hline \multirow{2}{*}{ No. } & \multirow{2}{*}{ Statements } & \multicolumn{4}{|c|}{ Values } \\
\cline { 4 - 7 } & STS & TS & N & S & SS \\
\hline 1. & I am proud to be part of the work environment. & & & & & \\
\hline 2. & $\begin{array}{l}\text { I am improving my career as a professional } \\
\text { banker. }\end{array}$ & & & & & \\
\hline 3. & I obey organizational rules. & & & & & \\
\hline 4. & $\begin{array}{l}\text { For me, pursuing the profession of banker is a } \\
\text { good achievement. }\end{array}$ & & & & & \\
\hline 5. & $\begin{array}{l}\text { I am very concerned about my career } \\
\text { development as an employee. }\end{array}$ & & & & & \\
\hline 6. & $\begin{array}{l}\text { I understand that my job requires specific } \\
\text { knowledge. }\end{array}$ & & & & & \\
\hline 7. & $\begin{array}{l}\text { I am loyal and believe that work is an } \\
\text { individual responsibility. }\end{array}$ & & & & & \\
\hline
\end{tabular}

\section{List of Statements for Moral Courage Variable}

Moral courage is a person's belief in certain morals and values in society that are not absolute and still consider the values from within and from the environment.

\begin{tabular}{|c|l|l|l|l|l|l|}
\hline \multirow{2}{*}{ No. } & \multirow{2}{*}{ Statements } & \multicolumn{3}{|c|}{ Values } \\
\cline { 3 - 6 } & & STS & TS & N & S & SS \\
\hline 1. & $\begin{array}{l}\text { Lies can be judged as moral or immoral things } \\
\text { depending on the situation. }\end{array}$ & & & & \\
\hline 2. & $\begin{array}{l}\text { Moral considerations leave individuals free to } \\
\text { form their code of ethics. }\end{array}$ & & & & \\
\hline 3. & I am against rude co-workers. & & & & & \\
\hline 4. & $\begin{array}{l}\text { A person's belief in certain morals and values } \\
\text { in society are not absolute. }\end{array}$ & & & & & \\
\hline 5. & $\begin{array}{l}\text { Moral courage differs from one community to } \\
\text { another. Its application also differs from one } \\
\text { situation to another. }\end{array}$ & & & & & \\
\hline 6. & $\begin{array}{l}\text { The notion of moral is difficult to solve } \\
\text { because the understanding of moral and } \\
\text { immoral is different for each individual. }\end{array}$ & & & & & \\
\hline 7. & $\begin{array}{l}\text { Each individual should set moral standards } \\
\text { because moral activities can be considered } \\
\text { immoral by other individuals. }\end{array}$ & & & & & \\
\hline
\end{tabular}




\section{List of Statements for Idealism Variable}

Idealism is a person's belief in certain morals and values in society that is applied absolutely without exception.

\begin{tabular}{|r|l|r|r|r|r|c|}
\hline \multirow{2}{*}{ No. } & \multirow{2}{*}{ Statements } & \multicolumn{4}{|c|}{ Values } \\
\cline { 2 - 6 } & STS & TS & N & S & SS \\
\hline 1. & $\begin{array}{l}\text { She/he make sure that the actions taken do not } \\
\text { hurt others. }\end{array}$ & & & & & \\
\hline 2. & $\begin{array}{l}\text { Harming others will always be wrong, even if it } \\
\text { can give them benefit. }\end{array}$ & & & & & \\
\hline 3. & $\begin{array}{l}\text { If an action harms another innocent person, } \\
\text { that action should not be done. }\end{array}$ & & & & & \\
\hline 4. & Moral action is one that is near perfection. & & & & & \\
\hline 5. & $\begin{array}{l}\text { Sacrificing the welfare of others is } \\
\text { something that should not be done. }\end{array}$ & & & & & \\
\hline 6. & $\begin{array}{l}\text { Believing in the truth that is believed is } \\
\text { imperative. }\end{array}$ & & & & & \\
\hline 7. & $\begin{array}{l}\text { A sense of happiness at work helps to } \\
\text { improve performance. }\end{array}$ & & & & & \\
\hline
\end{tabular}

\section{List of Statements for Altruistic Value Variable}

Altruism is the process of forming certain attitudes, beliefs, and views to help fellow humans and concerning others rather than themselves.

\begin{tabular}{|c|l|c|c|c|c|c|}
\hline \multirow{2}{*}{ No. } & \multirow{2}{*}{ Statements } & \multicolumn{3}{|c|}{ Values } \\
\cline { 5 - 7 } & & STS & TS & N & S & SS \\
\hline 1. & $\begin{array}{l}\text { I realize that the meaning of life is helping } \\
\text { each other. }\end{array}$ & & & & & \\
\hline 2. & I feel sad if my colleague gets hit. & & & & & \\
\hline 3. & $\begin{array}{l}\text { The work environment around me wants me to } \\
\text { help to solve problems faced by co-workers }\end{array}$ & & & & & \\
\hline 4. & $\begin{array}{l}\text { I believe that the truth must be told despite the } \\
\text { great risk to my career. }\end{array}$ & & & & & \\
\hline 5. & I try to help a co-worker who gets a disaster. & & & & & \\
\hline 6. & $\begin{array}{l}\text { I do not care about the assistance of co- } \\
\text { workers in my organizational environment. }\end{array}$ & & & & & \\
\hline 7. & $\begin{array}{l}\text { I do not feel happy when my co-workers are } \\
\text { successful. }\end{array}$ & & & & & \\
\hline
\end{tabular}




\section{List of Statement for Locus of Control Variable}

Internal locus of control is a people's belief that events in life result from their actions, individual abilities, and the behavior they create. External locus of control is a people's assumption that the surrounding environment controls events in their life, such as fate, destiny, or mere luck.

\begin{tabular}{|c|l|c|c|c|c|c|}
\hline \multirow{2}{*}{ No. } & \multirow{2}{*}{ Statements } & \multicolumn{4}{|c|}{ Values } \\
\cline { 5 - 7 } & & STS & TS & N & S & SS \\
\hline 1. & $\begin{array}{l}\text { I can do my job and assignments well as long as I } \\
\text { work hard. }\end{array}$ & & & & \\
\hline 2. & I believe I can control the life goals that I have set. & & & & & \\
\hline 3 & $\begin{array}{l}\text { I get rewarded according to my ability to complete } \\
\text { the tasks. }\end{array}$ & & & & & \\
\hline 4 & I will be responsible for every decision I make. & & & & & \\
\hline 5. & $\begin{array}{l}\text { It takes good fortune to become an accomplished } \\
\text { employee. }\end{array}$ & & & & & \\
\hline 6. & $\begin{array}{l}\text { Finding it easy to work at my workplace is a } \\
\text { fortune. }\end{array}$ & & & & & \\
\hline 7. & $\begin{array}{l}\text { I have to choose a co-worker who is in my favor } \\
\text { to get a good performance. }\end{array}$ & & & & & \\
\hline
\end{tabular}

\section{Thank you.}

